\title{
Presentation by Hussein A. Hassouna
}

\author{
Member of the International Law Commission
}

It is an honour for me to participate in this panel organized on the occasion of the seventieth anniversary of the International Law Commission. Our panel has addressed the topic of interaction between the Commission and the Sixth Committee. As a former member of the Sixth Committee and a current member of the Commission, this subject is of particular interest to me, having been involved in the work of both bodies and having witnessed their joint achievements in the field of codification and progressive development of international law. As the last speaker on this panel, I confirm that I agree with most of what has been said by the previous speakers. Allow me, however, to add my own perspective on some aspects of the subject matter.

I will begin by stating that the Commission's relationship with the Sixth Committee of the General Assembly is central to the Commission's work. In fact, the Commission has been able to have such an impact on international law because of its unique relationship with the Sixth Committee, a relationship which is both reactive and proactive, but at its roots, firmly founded upon interaction and communication.

The Commission proposes topics for the benefit of making the law more visible and more readily available for States, as well as presents reports on its work which serve as the basis for the Sixth Committee debates on the various topics. In turn, the Sixth Committee comments, provides data, and advises the Commission on how topics can be improved, and which topics should be prioritized. It is this relationship that has enabled States, developed and developing, to provide their input on the formulation of international law, and to help develop a truly transnational conception of international law.

Whereas the presentation by the Chair of the Commission of its annual report to the Sixth Committee has traditionally been the formal procedure leading to interaction between the two bodies, various activities have contributed in recent years to promote their relationships. Thus, in addition to the Chair of the Commission, a number of Commission members have been present during the Sixth Committee's debate on the report. An Interactive Dialogue has been held between Special Rapporteurs and interested delegates of the Sixth Committee on the margins of that debate. Informal briefings at other times of the year were provided by Commission members whenever they were present in New York, for interested Sixth Committee members. 
The current meeting of the Commission in New York during the first part of its seventieth session was also designed, in large part, to allow for greater formal and informal interaction between members of the Commission and of the Sixth Committee. Such interaction has enabled the Commission to discuss its work with the members of the Sixth Committee so as to allow the Commission to develop its activities, including the choice of its topics, in response to the needs and concerns of States. In addition, the current session in New York has been an opportunity for Commission members to explain their views on the Commission's topics at the numerous side events that were scheduled almost daily. Finally, the current session has further allowed another body, the Security Council, to be reminded of the achievements of the Commission. It was during its open debate held last week on the role of the Security Council in upholding international law that mention was made of the need to recognize the work of the principal legal organ to the United Nations, the International Law Commission, and its invaluable contributions over the years. Let us hope that such debate will lead the Security Council to ensuring that international law is applied and respected worldwide.

The success of the current meeting of the Commission in New York should encourage us to hold at least one part of its annual session each quinquennium in New York, so as to continue benefiting from greater formal and informal interaction between the Commission and the Sixth Committee. But let me reassure the Federal Government of Switzerland that the Commission will otherwise continue holding its annual sessions in Geneva and enjoy Swiss hospitality.

The Commission is generally autonomous with regard to its relationship with the Sixth Committee. The view of the General Assembly and the Sixth Committee has been that the Commission should have a substantial degree of autonomy and should not be subject to detailed directives from either the Sixth Committee or the General Assembly. Overall, the dependence of the Commission on the Sixth Committee and the General Assembly is based upon the guidance and information those two bodies can give to the Commission in its pursuit of the formation of international law and making it more clear and accessible. Otherwise, the Commission has great autonomy in deciding how to make this possible.

One must recognize, however, that although both the Commission and the Sixth Committee deal with issues pertaining to the codification and progressive development of international law, they differ in how they approach these issues, and one of the reasons for that lies in the composition of those bodies. Let us remember that the Commission is composed of independent experts who avoid politics in their discussions and in their selection of topics. 
Although they normally agree on most issues by consensus, on controversial issues they sometimes have to resort to voting. The Sixth Committee, on the other hand, is composed of State representatives who bring a political background and perspective to discussions. The independence of the Commission's experts encourages impartiality and objectiveness in approaching a certain subject, although they are often also influenced by their legal background and national experience.

On the other hand, the Sixth Committee members serve more as advocates for their individual States' interests. Indeed, the election by the General Assembly of the members of the Commission is regretfully always influenced by political considerations and is not mainly based on the qualifications of the candidates. In spite of this different dual approach, it is certain that both the objective perspective of the Commission members and the subjective perspective of the State representatives are required to address the codification of international law. Both perspectives are needed to get the full scope of international practice regarding a topic, but also to make sure that the codification of such a topic is relevant and useful to States. Without further collaboration, the work of the Commission is in danger of becoming academic and irrelevant, and the Sixth Committee is in danger of losing objective expertise on cutting edge issues in international law, an expertise that is greatly needed for a fruitful collaboration of the two bodies in the codification and development of international law.

In seeking to enhance its relationship with the Sixth Committee and other bodies, the Commission has dealt with that issue in the context of reviewing its methods of work. This process has been periodically undertaken by the Commission, at the request of the General Assembly at times, and more recently in 2011 and 2017 upon its own initiative. ${ }^{1}$ That review, aimed at expediting and streamlining the Commission's procedures, had an internal dimension covering how the Commission organizes its work, and an external dimension, as to how the work and the final product of the Commission is communicated to the General Assembly and its Member States, in particular, the Commission's relationship with the Sixth Committee and with governments regarding information on the State practice crucial to the Commission's work. The work of the Working Group on Methods of Work, which I have the honour of chairing, is still in progress and will resume at the upcoming Geneva part of the session

1 See ILC, 'Report of the International Law Commission on the work of its sixty-third session' [2011] II(2) ILC Ybk 176 at para 370. 'Report of the International Law Commission on the work of its sixty-ninth session' (2017) UN Doc A/72/10, 218 at para 283. 
in July. In my view, the experience learned through the Commission's interaction with the Sixth Committee at the current session in New York will certainly enrich the Working Group's debate on ways and means to enhance the Commission's relationship with the Sixth Committee. I do hope, however, that the Sixth Committee would undertake a similar review of its methods of work.

With regard to the outcome of the Commission's work products, we may notice its increasing practice of formulating "principles," "guidelines," "conclusions" or "report of study groups", rather than draft treaties or conventions. This development is likely a reaction to States' diminished support for creating binding obligations through treaties. In spite of that, the legal authority of such texts has been recognized through decisions of courts, organizations and in academia.

In addition, although the Commission's statute envisages full cooperation with governments in its deliberation process through reporting to the Sixth Committee and exchanging documents throughout the Commission's work on a document, in practice, there seems to be a disconnect between the expectations of the Commission and States. Even in some of the most recent successful work products by the Commission, the articles on responsibility of States for internationally wrongful acts ${ }^{2}$ and the articles on the expulsion of aliens, ${ }^{3}$ the Sixth Committee continues to postpone consideration of their final form to future sessions. While the Sixth Committee does not explain its decisions regarding the final outcome of the Commission's work products, it cites States' hesitation about certain aspects and often requests further comments from governments. This was the case, for instance, with the topics "Consideration of prevention of transboundary harm from hazardous activities" and "Allocation of loss in the case of such harm ${ }^{4}$ and Diplomatic protection". ${ }^{5}$ On such a problem, there must be room for improvement in the communication between the Commission and the Sixth Committee. One suggestion to prevent stalling of a final product of the Commission would be for States to submit preferences for the final outcome of a given topic in their comments throughout the deliberation process. This would allow the Special Rapporteur and the Commission members to learn where States stand, and what they expect out of the topic and how they value the work generally. Another suggestion to face that

2 UNGA Res 56/83 (12 December 2001), annex.

3 ILC, 'Draft articles on the expulsion of aliens' (2014) UN Doc A/69/10, 11.

4 See Unga Res 56/82 (12 December 2001), 61/36 (4 December 2006), 62/68 (6 December 2007), 65/28 (6 December 2010), 68/114 (16 December 2013) and 71/143 (13 December 2016).

5 See Unga Res 61/35 (4 December 2006), 62/67 (6 December 2007), 65/27 (6 December 2010), 68/113 (16 December 2013) and 71/142 (13 December 2016). 
problem would be to encourage the General Assembly and the Sixth Committee to recommend to the Commission topics for codification. This procedure resulted in the successful Rome Statute of the International Criminal Court, ${ }^{6}$ and could be replicated to ensure that the Commission is focusing on topics that are ripe for codification and have the necessary political support by the General Assembly.

In proceeding with the analysis of topics on its agenda, the Commission always seeks the opinion of States through their written comments or oral views expressed during the Sixth Committee debates. It is noteworthy that the number of States that submit comments has consistently been limited. Moreover, the commenting States do not reflect the diverse views held by Member States, and the African and Asian perspectives are particularly underrepresented. Despite continuous calls by Commission members for States to submit comments on a given topic, comments from under-represented States remain disproportionately low. This has resulted in the absence of their perspectives in the process of formulating universal rules of international law. In my view, the solution lies in encouraging their participation through regional United Nations procedures, as well as regional organizations. This has inspired, for instance, the members of the Commission from States belonging to the African Group to plan a meeting this week with the African legal advisers of the Sixth Committee, to coordinate the African position on the various topics of the Commission's agenda and encourage African participation in the work of the Commission. In addition, an organization like the Asian-African Legal Consultative Organization (AALCO) can play an important role in coordinating the position of its members towards the work of the Commission and induce them to submit their views on the various topics on its agenda.

It is occasionally argued that the Commission has completed the bulk of its work and faces an identity crisis during a time of fragmentation of international law. While the creation in the Commission of the Working Group on the Long-term Programme of Work has ensured a steady flow of practical and worthwhile suggestions for the Commission's future work, it is generally recognized that the Commission may not be the proper institution to address emerging technical areas of international law. Indeed, the proliferation of specialized bodies to codify certain fields of international law, such as the law of outer space ${ }^{7}$ and the law of economic relations, ${ }^{8}$ has reduced the scope

6 Adopted 17 July 1998, entered into force 1 July 2002, 2187 UNTS 3.

7 For instance, the Committee on the Peaceful Uses of Outer Space <http://www.unoosa.org/ oosa/en/ourwork/copuos/index.html>.

8 For instance, the United Nations Commission on International Trade Law (UNCITRAL) $<$ https://uncitral.un.org/>. 
of the Commission's work. However, I am convinced that the Commission could address more complex and specialized topics. For example, the Special Rapporteur for the topic of protection of the atmosphere proactively brought scientists to earlier Commission sessions to inform members of the scientific nuances of the law of the atmosphere. ${ }^{9}$ In my view, the Commission should explore more specialized areas of international law, and by doing so, it could benefit from outside consultations, either with scientists or experts in the relevant field, or with specialized international institutions.

In conclusion, I would assert that, although the future of the Commission has been claimed by some commentators to be uncertain, its institutional knowledge, its framework within the General Assembly and its partnership with the Sixth Committee, make it uniquely positioned to continue to codify and progressively develop international law. Indeed, the Commission plays a greater role and assumes a more important responsibility when States fail to agree on the development of international law. The International Law Commission has always adjusted to the needs of the international community. Now, as the Commission ventures into areas of international law that are not as settled as the topics it addressed seventy years ago, it should be attuned to how it can serve its mandate while responding to the needs of all States.

9 See ILC, 'Report of the International Law Commission on the work of its sixty-fifth session' (2015) UN Doc A/70/10 22 at para 49. 
Member of the International Law Commission - 9789004434271 Downloaded from Brill.com@4/26/2023 11:10:40AM via free access 